\title{
Carbohydrate and Organic Nitrogen Concentrations within Range Grass Parts at Maturity
}

\section{J. PERRY, JR. AND LOWELL E. MOSER}

Highlight: Total nonstructural carbohydrate (TNC) levels were significantly different among eight range grasses at maturity. Roots, rhizomes, and stem bases (storage organs), differed significantly in percentage TNC within rhizomatous and bunch-type (non-rhizomatous) grasses. Percent organic nitrogen differed significantly among grasses and storage organs but not to the same extent as occurred with TNC. We suggest that TNC concentrations of storage organs must be determined for each grass before sampling for TNC levels, in order to locate storage organs with greatest TNC concentration.

Total nonstructural carbohydrate accumulation, often referred to as food or carbohydrate reserves, have been shown to play an important role in the management of range plants. In the authors' opinion, when rangeland is managed intensively, the cycling of carbohydrate reserves of range plants should be considered carefully because of its importance in the vigor and survival of plants.

Carbohydrate reserves of perennial plants are important for winter survival, initiation of spring growth, and regrowth after herbage removal or any time the photosynthetic production is inadequate to meet growth demands (White, 1973). The extent of carbohydrate reserve depletion following herbage removal is dependent on the plant's developmental stage when clipped, clipping height, and frequency of clipping (Donart

Authors are assistant professor and associate professor of agronomy, University of Nebraska, Lin coln.

Research reported is a contribution of the Nebraska Agricultural Experiment Station, published with the approval of the director as No. 3680 Journal Series.

Manuscript received September 17, 1973. and Cook, 1970; Jameson, 1963; and McCarty and Price, 1942). Clipping during the spring affects carbohydrate reserve levels present during the fall (Hyder and Sneva, 1963). There are many environmental conditions that interact with defoliation to affect the level of carbohydrate reserves (White, 1973).

There are two groups of perennial grasses based on the type of nonstructural polysaccharide accumulated (Smith, 1968; and Weinmann and Reinhold, 1946). Grasses of subtropical and tropical origin accumulate starch, while grasses of temperate origin accumulate fructosans as their main polysaccharide.

Most investigators have considered only the nonstructural carbohydrates as reserve constituents, capable of being mobilized and redistributed, and not the organic nitrogenous compounds which also may be involved. Often no definite trends in organic nitrogen level are evident, as there are with carbohydrates; however, Dilz (1966) in studying perennial ryegrass (Lolium perenne L.), concluded that proteinaceous material should be regarded as reserve constituents. Davidson and Milthorpe (1966) concluded that nonstructural carbohydrates formed only a part of the labile pool which provided substrates for respiration and new growth of orchardgrass (Dactylis glomerata L.). They suggested that proteins must have been remobilized because the amount of nonstructural carbohydrates was inadequate to account for respiration and new growth of roots and shoots following severe herbage removal.

Total nonstructural carbohydrates (TNC) of herbaceous plants are generally stored in underground and ground level organs, which include roots, tubers, rhizomes, stolons, crowns, and stem bases. However, storage may occur temporarily in all 
Table 1. Percentage TNC obtained from four plant parts of four rhizomatous grasses sampled at the onset of winter dormancy.

\begin{tabular}{lccll}
\hline \hline \multicolumn{1}{c}{ Grasses } & Roots & Rhizomes & $\begin{array}{l}\text { Stem } \\
\text { bases }^{1}\end{array}$ & $\begin{array}{l}\text { Upper } \\
\text { stems }\end{array}$ \\
\hline Sand bluestem & $21.4 \mathrm{a}^{3}$ & $12.1 \mathrm{~b}$ & $4.9 \mathrm{f}$ & $0.4 \mathrm{~g}$ \\
Prairie sandreed & $12.2 \mathrm{~b}$ & $8.9 \mathrm{~cd}$ & $8.1 \mathrm{de}$ & $4.8 \mathrm{f}$ \\
Indiangrass & $5.6 \mathrm{ef}$ & $12.9 \mathrm{~b}$ & $8.2 \mathrm{de}$ & $0.6 \mathrm{~g}$ \\
Switchgrass & $14.6 \mathrm{~b}$ & $11.8 \mathrm{bc}$ & $7.3 \mathrm{def}$ & $1.1 \mathrm{~g}$ \\
\hline
\end{tabular}

${ }^{1}$ Stem bases composed the lower $10 \mathrm{~cm}$ of all stems.

${ }^{2}$ Stems composed all stem material except the lower $10 \mathrm{~cm}$.

${ }^{3}$ Numbers within a column or row followed by the same letter do not differ significantly at the 5\% level using Duncan's new multiple range test.

plant parts. The relative importance of reserve storage areas varies among species (Cook, 1966).

This paper reports the content of TNC and organic nitrogen in the roots, rhizomes, stem bases, and remaining stem material of eight range grasses at the onset of winter dormancy. The objective was to determine the location of greatest TNC and organic nitrogen concentrations in the grasses. It is the intent of this paper to indicate the importance of locating specific storage organ(s) of a grass before proceeding with $\mathrm{TNC}$ analysis.

\section{Materials and Methods}

In October, 1972, six samples each of blue grama (Bouteloua gracilis (H.B.K.) Lag.), Canada wildrye (Elymus canadensis L.), prairie sandreed (Calamovilfa longifolia (Hook.) Hack.), little bluestem (Schizachrium scoparium Nash.), Indiangrass (Sorghastrum nutans (L.) Nash.), sand bluestem (Andropogon hallii Hack.), sand lovegrass (Eragrostis trichodes (Nut1.) Wood), and switchgrass (Panicum virgatum L.) were collected at random from a sands range site in the Sandhills near Halsey, Nebraska. The site had not been grazed or clipped for 5 years. All eight grasses are common throughout the Sandhills.

The plants were dug to a depth of $20 \mathrm{~cm}$, frozen, and then separated into roots, rhizomes if present, stem bases, and the remaining stem material. The following year's attached tillers and/or buds were left intact with the stem bases. Leaves and any previous year's plant tissue were excluded. The lower 10 $\mathrm{cm}$ of stems were considered stem bases for the tall grasses: Canada wildrye, prairie sandreed, Indiangrass, switchgrass, and sand bluestem. The lower $5 \mathrm{~cm}$ were considered stem bases for blue grama, sand lovegrass, and little bluestem. After separation into the respective plant parts, the material was washed and placed in a forced air oven at $100^{\circ} \mathrm{C}$ for 60 minutes followed by 24 hours at $70^{\circ} \mathrm{C}$. The dried samples were ground through a 40-mesh Wiley Mill screen and stored for TNC and nitrogen analyses.

The method of TNC analysis used was first described by Weinmann (1947) and later modified by Lindahl et al. (1949) and Smith (1969). The TNC was extracted with a takadiastase enzyme solution. Samples were randomly selected and split in half to determine the takadiastase hydrolyzable carbohydrates (primarily starch and sucrose) and the $0.1 \mathrm{~N} \mathrm{H}_{2} \mathrm{SO}_{4}$ hydrolyzable carbohydrates (primarily fructosans). The only grass showing an appreciable amount of fructosan accumulation was Canada wildrye, so all samples of Canada wildrye were hydrolyzed with $0.1 \mathrm{~N} \mathrm{H}_{2} \mathrm{SO}_{4}$ while all others were hydrolyzed with the takadiastase enzyme only. This is in agreement with Smith (1968). Reducing power was measured by the Shaeffer-Somogyi copper-iodometric titration method as described by Heinze and Murneek (1940). Results are reported
Table 2. Percentage TNC obtained from three plant parts of four bunch grasses sampled at the onset of winter dormancy.

\begin{tabular}{lccl}
\hline Grasses & Roots & $\begin{array}{l}\text { Stem } \\
\text { bases }^{1}\end{array}$ & $\begin{array}{l}\text { Upper } \\
\text { stems }^{2}\end{array}$ \\
\hline Sand lovegrass & $4.2 \mathrm{c}^{3}$ & $12.0 \mathrm{a}$ & $3.4 \mathrm{~cd}$ \\
Blue grama & $6.6 \mathrm{~b}$ & $13.3 \mathrm{a}$ & $1.7 \mathrm{cde}$ \\
Little bluestem & $12.5 \mathrm{a}$ & $10.8 \mathrm{a}$ & $0.4 \mathrm{e}$ \\
Canada wildrye & $7.1 \mathrm{~b}$ & $7.6 \mathrm{~b}$ & $1.0 \mathrm{de}$ \\
\hline
\end{tabular}

${ }^{1}$ Stem bases composed the lower $5 \mathrm{~cm}$ of all stems for sand lovegrass, blue grama, and little bluestem, and $10 \mathrm{~cm}$ for Canada wildrye.

${ }^{2}$ Remaining stem material except for stem bases.

${ }^{3}$ Numbers within a column or row followed by the same letter do not differ significantly at the $5 \%$ level using Duncan's new multiple range test.

on a percentage dry weight basis using a glucose standard.

Organic nitrogen content of the plant material was measured by the Kjeldahl procedure as described by Bremner (1965). This method measures nitrogen in the reduced form only. Therefore, the organic nitrogen we are reporting includes nitrogen in protcin, amino acids, amides, and other organic compounds.

For statistical analyses the grasses were separated into those having rhizomes (rhizomatous) and those not having rhizomes (bunch-type). Each group was analyzed as a Complete Random Design for TNC and organic nitrogen.

\section{Results and Discussion}

\section{Total Nonstructural Carbohydrates}

Prior to measuring carbohydrate reserves of a perennial plant, the portion of the plant that accumulates the greatest concentration of reserves must be determined, since it is too laborious to sample all possible storage organs under field conditions. Presumably, sampling the storage organ(s) with the greatest concentration would indicate TNC trends induced by environmental or management factors.

Percent total nonstructural carbohydrates (TNC) obtained from the four plant parts of the rhizomatous grasses are presented in Table 1. Dry weights are not reported because of the difficulty in distinguishing individual rhizomatous plants and recovering all root material. Root material was sampled to the $20 \mathrm{~cm}$ depth only.

Rhizome dry weights were one-to-two times that of root dry weights. Stem TNC of all grasses were significantly lower than other plant parts as expected because of the mature stage of development. Prairie sandreed had significantly higher TNC in the stems than the other grasses.

Percentage TNC in the various storage organs differed significantly among grasses. Sand bluestem and prairie sandreed had significantly greater TNC in the roots than in rhizomes or stem bases. Thus, collection of a major portion of the root material in sand bluestem and prairie sandreed may be necessary for TNC analysis. Stem bases alone may not reveal carbohydrate depletion and replacement trends. However, the greatest percentage TNC occurred in the rhizomes of Indiangrass. Thus, the data indicate that sampling rhizomes and stem bases of Indiangrass would be sufficient to detect TNC trends. Switchgrass had a significantly higher TNC in the roots and rhizomes than in the stem bases. Thus, sampling only stem bases for TNC would not be adequate in switchgrass.

Percentage TNC obtained from the three plant parts of the bunchtype grasses are presented in Table 2. Stem possessed significantly lower TNC than other plant parts as occurred with the rhizomatous grasses (Table 1). Root dry weights were 
Table 3. Percentage organic nitrogen obtained from four plant parts of four rhizomatous grasses sampled at the onset of winter dormancy.

\begin{tabular}{lllll}
\hline \hline \multicolumn{1}{c}{ Grasses } & Roots & Rhizomes & $\begin{array}{c}\text { Stem } \\
\text { bases }^{1}\end{array}$ & $\begin{array}{c}\text { Upper } \\
\text { stems }^{2}\end{array}$ \\
\hline Sand bluestem & $0.59 \mathrm{def}^{3}$ & $0.58 \mathrm{def}$ & $0.61 \mathrm{de}$ & $0.11 \mathrm{~g}$ \\
Prairie sandreed & $0.51 \mathrm{ef}$ & $0.67 \mathrm{~cd}$ & $0.59 \mathrm{def}$ & $0.18 \mathrm{~g}$ \\
Indiangrass & $0.51 \mathrm{ef}$ & $1.02 \mathrm{a}$ & $0.86 \mathrm{~b}$ & $0.10 \mathrm{~g}$ \\
Switchgrass & $0.43 \mathrm{f}$ & $0.82 \mathrm{bc}$ & $0.66 \mathrm{de}$ & $0.16 \mathrm{~g}$
\end{tabular}

'Stem bases composed the lower $10 \mathrm{~cm}$ of all stems.

${ }^{2}$ Stems composed all stem material except the lower $10 \mathrm{~cm}$.

${ }^{3}$ Numbers within a column or row followed by the same letter do not differ significantly at the $5 \%$ level using Duncan's new multiple range test.

generally about half that of stem bases of the bunch-type grasses.

Sand lovegrass and blue grama had the greatest percentage of carbohydrate reserves in the stem bases. Sampling the lower $5 \mathrm{~cm}$ of the stems near maturity would appear to be adequate to determine TNC concentrations in the se two grasses due to the much lower concentration in the roots. Little bluestem and Canada wildrye showed no significant difference between roots and stem bases. Bécause of the high stem base dry weight and TNC concentration, higher total amounts of TNC may occur in stem bases rather than in roots.

Locations of carbohydrate reserve storage organs were different within rhizomatous and bunch-type grasses. Therefore we are suggesting that TNC concentrations of storage organs must be determined for each grass before sampling for TNC levels. The specific carbohydrate reserve storage organ(s) may change among developmental stages as well.

\section{Organic Nitrogen}

Organic nitrogen contents of the various plant parts of the rhizomatous and bunch-type grasses are presented in Tables 3 and 4 , respectively. In all grasses organic nitrogen content in the stem was significantly less than that of root, rhizome, or stem base. The low nitrogen values for stems was expected because nitrogen content declines with advancing maturity and most particularly during late summer and fall. The low organic nitrogen content of the stems may be due partially to translocation of amino acids and other organic nitrogen compounds to the roots, rhizomes, and stem bases and due to leaching of soluble nitrogen compounds.

Within each grass, plant parts did not differ in organic nitrogen (even when expressed as percentage protein) to the extent that each changed in TNC content. Rhizomes followed by the stem bases tended to have higher organic nitrogen contents than the roots of the rhizomatous grasses with the exception of sand bluestem, where roots, rhizomes, and stem bases did not differ significantly. Indiangrass, sand lovegrass, and Canada wildrye had higher nitrogen contents in each plant part than the other grasses.

In sand lovegrass, blue grama, and Canada wildrye, the organic nitrogen content if expressed as protein (multiply by 6.25) was the same as the TNC content of the root, and approximately one-half of the TNC content in the stem base. This represents a considerable potential reserve component. Further research is needed to determine if the organic nitrogen
Table 4. Percentage organic nitrogen obtained from three plant parts of four bunch grasses sampled at the onset of winter dormancy.

\begin{tabular}{llll}
\hline \hline Grasses & Roots & $\begin{array}{l}\text { Stem } \\
\text { bases }^{1}\end{array}$ & $\begin{array}{l}\text { Upper } \\
\text { stems }^{2}\end{array}$ \\
\hline Sand lovegrass & $0.70 \mathrm{bc}^{3}$ & $1.09 \mathrm{a}$ & $0.26 \mathrm{de}$ \\
Blue grama & $0.78 \mathrm{~b}$ & $0.85 \mathrm{ab}$ & $0.30 \mathrm{de}$ \\
Little bluestem & $0.45 \mathrm{~d}$ & $0.50 \mathrm{~cd}$ & $0.11 \mathrm{e}$ \\
Canada wildrye & $0.96 \mathrm{ab}$ & $0.75 \mathrm{~b}$ & $0.27 \mathrm{e}$ \\
\hline
\end{tabular}

${ }^{1}$ Stem bases composed the lower $5 \mathrm{~cm}$ of all stems for sand lovegrass, blue grama, and little bluestem, and $10 \mathrm{~cm}$ for Canada wildrye.

${ }^{2}$ Remaining stem material except for stem bases.

${ }^{3}$ Numbers within a column or row followed by the same letter do not differ significantly at the $5 \%$ level using Duncan's new multiple range test.

compounds are remobilized and used in growth and respiration. A similar relationship occurred in Indiangrass and switchgrass although not to the same extent as in sand lovegrass, blue grama, and Canada wildrye.

These data suggest that appreciable organic nitrogen concentrations exist in these grasses and they should receive further attention by researchers working with perennial range grasses. These compounds may serve as a labile energy pool for respiration and new growth of roots and shoots as suggested by Davidson and Milthorpe (1966) working with orchardgrass.

\section{Literature Cited}

Bremner, J. M. 1965. Total Nitrogen.In C. A. Black et al. (ed.) Methods of Soil Analysis, Agronomy 9:1149-1178.

Cook, C. Wayne. 1966. Carbohydrate reserves in plants. Utah Res. Ser. 31. Logan, Utah. 47p.

Davidson, J. L., and F. L. Milthorpe. 1966. The effect of defoliation on the carbon balance in Dactylis glomerata. Ann. Bot. 30:185-198.

Dilz, K. 1966. The effect of nitrogen nutrition and clipping frequency on regrowth of perennial ryegrass. 10th Int. Grassland Congr., Proc. (Helsinki, Finland). p. 160-164.

Donart, G. B., and C. W. Cook. 1970. Carbohydrate reserve content of mountain range plants following defoliation and regrowth. J. Range Manage. 23:15-19.

Heinze, P. H., and A. E. Murneek. 1940. Comparative accuracy and efficiency in determination of carbohydrates in plant material. Missouri Agr. Exp. Sta. Res. Bull. 314. 23p.

Hyder, D. N., and F. A. Sneva. 1963. Morphological and physiological factors affecting grazing management of crested wheatgrass. Crop Sci. 3:267-271.

Jameson, D. A. 1963. Responses of individual plants to harvesting. Bot. Rev. 29:532-594.

Lindahl, I., R. E. Davis, and W. O. Shepherd. 1949. The application of the total available carbohydrate method to the study of carbohydrate reserves of switch cane (Arundinaria tecta). Plant Physiol. 24:285-294.

McCarty, E. C., and R. Price. 1942. Growth and carbohydrate content of important mountain forage plants in central Utah as affected by clipping and grazing. U. S. Dep. Agr. Tech. Bull. 818. 51p.

Smith, Dale. 1968. Classification of several native North American grasses as starch or fructosan accumulators in relation to taxonomy. J. Brit. Grassl. Soc. 23:306-309.

Smith, Dale. 1969. Removing and analyzing total nonstructural carbohydrates from plant tissue. Wisconsin Agr. Exp. Sta. Res. Rep. $41.11 \mathrm{p}$.

Weinmann, H., and L. Reinhold. 1946. Reserve carbohydrates in South African grasses. J. South African Bot. 12:57-73.

Weinmann, H. 1947. Determination of total available carbohydrates in plants. Plant Physiol. 22:279-290.

White, L. M. 1973. Carbohydrate reserves of grasses: a review. J. Range Manage. 26:13-18. 